\title{
Medical treatment of peptic ulcer disease: Should the emphasis be altered in view of laparoscopic surgery?
}

ABR THOMSON MD PhD FRCPC FACP FRS FACC

\begin{abstract}
ABR THOMSON. Medical treatment of peptic ulcer disease: Should the emphasis be altered in view of laparoscopic surgery? Can J Gastroenterol $1994 ; 8(3): 199-204$. In the past $\mathrm{H}_{2}$-receptor antagonist era, there was initially a lull as more and more 'me-too' drugs were developed. Then came the excitement of the proton pump inhibitors and the controversy of the pros and cons of moderate versus potent acid inhibition. The most recent explosion of knowledge has been in the discussion of $\mathrm{pH}$ versus Helicobacter pylori, but on the horizon is lurking the promise of the resurgence of the surgical option.
\end{abstract}

Key Words: Laparoscopic surgery, Management, Peptic ulcer disease

\section{Traitement médical de l'ulcère gastro-duodénal. La chirurgie laparoscopique indique-t-elle une nouvelle voie?}

RÉSUMÉ : Au cours de la récente époque anti- $\mathrm{H}_{2}$, on a d'abord connu une période lente avant que n'apparaissent de nouveaux médicaments toujours plus nombreux. Puis, vinrent les inhibiteurs de la pompe à protons, qui ont soulevé l'enthousiasme et la controverse au sujet des avantages et des inconvénients de l'inhibition modérée ou marquée de l'acide. Les découvertes les plus récentes portent sur le $\mathrm{pH}$ versus Helicobacter pylori, mais on note à l'horizon les promesses que pourraient receler les interventions chirurgicales.
$\mathrm{T}^{\mathrm{H}}$ HE NUMBER OF SURGICAL PROCEdures performed on patients with peptic ulcer disease has declined dramatically in the past 20 years. This decline was associated with, but not en- tirely explained by, the introduction in the mid-1970s of, first, cimetidine and then other $\mathrm{H}_{2}$-receptor antagonists such as ranitidine, famotidine and nizatidine $(1,2)$. With the current possibil-
Presented at the Symposium on Minimal Access Surgery in Saskatoon, Saskatchewan on August 7 and 8, 1992

Nutrition and Metabolism Research Group, Division of Gastroenterology, Department of Medicine, University of Alberta, Edmonton, Alberta

Correspondence and reprints: Dr ABR Thomson, 519 Robert Newton Research Building, University of Alberta, Edmonton, Alberta T6G 2C2. Telephone (403) 492-6490, Fax (403) $492-7964$

Received for publication September 29, 1993. Accepted November 15, 1993 ity of reducing intragastric hydrogen ion $\left(\mathrm{H}^{+}\right)$concentration by greater than $99 \%$ via proton pump inhibitors such as omeprazole, one might have hoped that peptic ulcer disease would be a condition of the past. This has not occurred. One might also have wondered whether the medical management of peptic ulcer disease would completely replace surgical therapy of peptic ulcer disease, but that too has not occurred because of the problems of ulcer resistance, recurrence, drug complications and cost. With the benefits of minimal access surgery on the close horizon, these potential drawbacks of medical therapy need to be examined in closer detail, and need to be examined against the background of the possibility of curing peptic ulcer disease with the eradication of commonly associated Helicobacter pylori infections.

\section{RESISTANCE}

While the $\mathrm{H}_{2}$-receptor antagonists and proton pump inhibitors are effective in healing duodenal and benign gastric ulcers, there remains a small group of peptic ulcer disease patients who are apparently resistant to therapy. The mechanisms of this resistance have not been established, and while some patients respond when switched from one $\mathrm{H}_{2}$-receptor antagonist to another, others only heal when switched from 
an $\mathrm{H}_{2}$-receptor antagonist to another therapeutic agent, such as a proton pump inhibitor. The recent report of Lauritsen et al (3) has shown that $100 \%$ of more than 1000 patients with duodenal ulcers healed after a course of omeprazole, so there may prove to be relatively few duodenal ulcer patients who do not heal on omeprazole.

Ulcer symptoms do not necessarily occur when the ulcer is present (4). The complications of hemorrhage and perforation may be independent of whether the ulcer has been clinically apparent or silent (5). In persons taking nonsteroidal anti-inflammatory drugs (NSAIDs), hemorrhage from the silent ulcer is frequent (4). Persons with a past history of peptic ulcer disease who are not on maintenance therapy may also present with complicated silent ulcers (6), and even patients on maintenance therapy may develop silent ulcers $(7,8)$.

The problem of 'resistance' to the usual therapeutic doses of ulcer-healing drugs has been reviewed $(9,10)$. Duodenal ulcers are defined as 'resistant' or 'refractory' if they are unhealed after treatment with the usual healing doses of $\mathrm{H}_{2}$-receptor antagonists after eight weeks; less than $10 \%$ of duodenal ulcers are resistant when using this definition (11). When ulcers fail to heal, a number of diagnostic considerations must be undertaken (12). In the patient who has been on $\mathrm{H}_{2}$-receptor antagonists for eight weeks, persistence of symptoms is not necessarily associated with persistence of ulceration. If persistent ulceration is confirmed on endoscopy, it is important to assess the patient's compliance, use of NSAIDs or smoking, the possible previous presence of a larger ulcer (which takes longer to heal than a small ulcer), gastric hypersecretory state or a persistent $H$ pylori infection $(13,14)$.

Failure of conventional doses of $\mathrm{H}_{2}$ receptor antagonists to inhibit gastric acid secretion has been reported in some duodenal ulcer patients (15). The inhibitory effect of $\mathrm{H}_{2}$-receptor antagonists on $24 \mathrm{~h}$ intragastric $\mathrm{pH}$ profiles may be less in nonresponders than in responders (16). This cannot be the entire explanation for resistance to $\mathrm{H}_{2}$ receptor antagonist treatment because some patients may develop nocturnal achlorhydria on $\mathrm{H}_{2}$-receptor antagonists and yet still not heal $(17,18)$.

Therapeutic manipulations that have been used to treat resistant ulcers include: higher than 'normal' doses of $\mathrm{H}_{2}$-receptor antagonists; use of 'normal' doses of $\mathrm{H}_{2}$-receptor antagonists for longer periods $(15,19,20)$; or switching from an $\mathrm{H}_{2}$-receptor antagonist to a proton pump inhibitor (21), to colloidal bismuth subcitrate (22) or to a prostaglandin analogue (23). If there is $\mathrm{H}$ pylori infection associated with a duodenal ulcer, one therapeutic approach is to use triple antibiotic therapy or omeprazole plus amoxicillin. In the patient who has not healed with $\mathrm{H}_{2}$-receptor antagonists and who has a highly selective vagotomy, the incidence of recurrence of duodenal ulcers is 10 times greater than if the ulcer were not resistant (24).

\section{RECURRENCE}

Once acute therapy has been discontinued, peptic ulcer disease recurs at a rate of approximately $80 \%$ per year, and $90 \%$ of ulcers relapse within two years of healing irrespective of the initial ulcer healing therapy (25). This rate of recurrence can be reduced with the continuous administration of $\mathrm{H}_{2}$ receptor antagonists, but despite maintenance therapy, some patients will have a symptomatic recurrence and some will have an asymptomatic recurrence. The rates of duodenal ulcer recurrence may prove to be even lower with maintenance therapy using a proton pump inhibitor. Most of these recurrent ulcers will heal when the dose of maintenance medication is increased to approximately twice the high levels of $\mathrm{H}_{2}$-receptor antagonists needed for acute therapy.

Wormsley (26) has outlined the different methods of treating ulcers: the variants of therapy with anti-ulcer drugs range from demand (taking a few tablets of an anti-ulcer drug for a few days while symptoms persist) to periodic (taking a few tablets at specific intervals, such as weekends or seasonally), through intermittent, rehealing each symptomatic relapse with standard courses of anti-ulcer drugs given for one to two months to long term, continuous (maintenance) treatment.

Weekend therapy with ranitidine $300 \mathrm{mg}$ may be comparable with continuous use of ranitidine $150 \mathrm{mg}$ at night-time (27). Seasonal treatment with ranitidine in March and April and again in September and October results in relapse rates almost twice as high over 24 months of therapy, compared with continuously treated patients (28). Giving therapy for symptomatic relapse (intermittent treatment) has been discussed (29); its potential contraindications extend to include most patients with relapsing ulcer disease.

Are agents other than $\mathrm{H}_{2}$-receptor antagonists useful for maintenance therapy? Sucralfate may be effective for maintenance therapy in duodenal ulcers $(30,31)$ but not for gastric ulcers (32). Pirenzepine is of limited use for maintenance therapy (33). The results of a large multicentre maintenance trial of omeprazole in patients with duodenal ulcers will soon be available.

American views of maintenance therapy have been analyzed (34). It remains controversial whether duodenal ulcers 'burn out' over time $(34,35)$. In any case, maintenance therapy should be continued for at least one year (36). When point prevalence rates of recurrence of duodenal ulcers during maintenance therapy are assessed, the cumulative rate of recurrence is $48 \%$ after 12 months, and $71 \%$ of these recurrences are painless (8).

With cimetidine maintenance treatment, symptomatic relapse occurs in $17.2 \%$ of duodenal ulcer patients during the first year, $9.6 \%$ in the second year and $8.8 \%$ in the third year (37). In another study of patients with duodenal or gastric ulcers maintained on cimetidine for as long as six years, life-table analysis showed that the cumulative symptomatic relapse rates for duodenal ulcers were $13,19,24,26$ and $28 \%$ during the first five years (38). Thus, maintenance therapy may reduce the risk of ulcer recurrence, but even better maintenance therapy would be desirable.

While maintenance therapy may reduce the risk of ulcer recurrence, does it reduce the risk of complications? Yes over a three-year period of mainte- 
nance therapy, the cumulative rate of ulcer hemorrhage during periods without active treatment was approximately $15 \%$ compared with an incidence of ulcer bleeding during six years of continuous maintenance therapy of approximately $1.3 \%$ (39).

Sonnenberg (40) developed a Markov chain to study the long term outcome of maintenance with $\mathrm{H}_{2}$-receptor antagonists, intermittent treatment with $\mathrm{H}_{2}$-receptor antagonists and proximal gastric vagotomy. With maintenance treatment, the rate of complications and the number of deaths related to ulcers were slightly higher than after proximal gastric vagotomy, but because the few deaths from this procedure occur at treatment start, the loss of life-years during maintenance treatment exceeded that of proximal gastric vagotomy only after 20 years. Thus, 'surgical maintenance therapy' with proximal gastric vagotomy may be a useful option for the patient requiring prolonged suppression of gastric acidity.

\section{HELICOBACTER PYLORI}

Many duodenal or gastric ulcer patients are faced with the prospect of remaining on medication for the rest of their lives. In some persons the tendency for ulcer recurrence may be the result of persistence of an infection with $H$ pylori. Strong evidence suggesting causation of duodenal ulcers by $\mathrm{H}$ pylori has been reviewed (41). H pylori is found in more than $90 \%$ of persons with duodenal ulcers $(42-46)$, but in about one patient in 10, duodenal ulcers will occur in the absence of $\mathrm{H}$ pylori (demonstrated with the methods currently available). The eradication of $H$ pylori is associated with the healing of gastritis (44), and a marked reduction in the rate of recurrence of duodenal ulcers $(43,47-51)$.

Ulcers may recur in patients who do not have $H$ pylori infection, and patients with $H$ pylori do not necessarily have ulcers or ulcer recurrences $(43,49)$. Eradication of $H$ pylori using tetracycline $2 \mathrm{~g}$, metronidazole $750 \mathrm{mg}$ and bismuth subsalicylate five or eight tablets (151 mg bismuth/tablet) plus ranitidine $300 \mathrm{mg}$ in patients with duode-

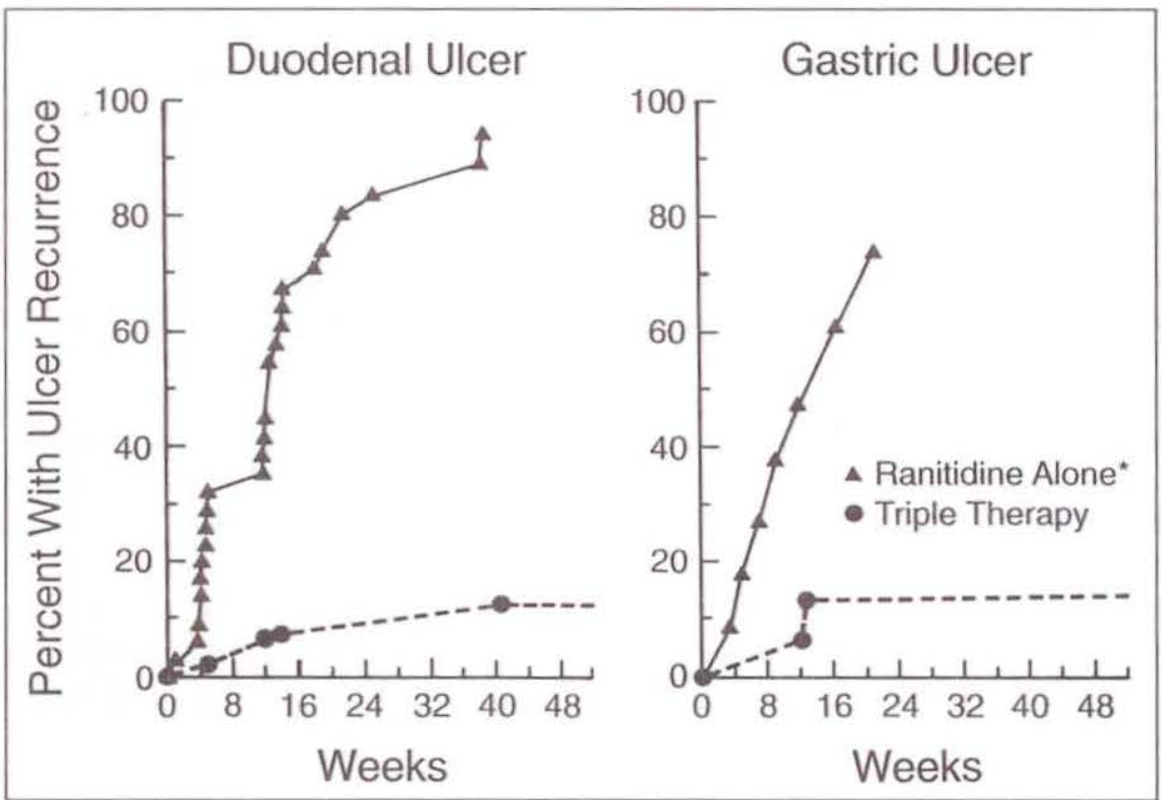

Figure 1) Life-table recurrence of duodenal and gastric ulcers for one year after successful healing with ranitidine alone or triple therapy plus ranitidine (adapted with permission from Graham et al Ann Intern Med 1992;116:70)

nal or gastric ulcers is associated with much lower rates of ulcer recurrence at 48 weeks (Figure 1). Life-table analysis demonstrates that patients whose ulcers have healed but who continue to have $H$ pylori infection have a $95 \%$ chance of developing a recurrent ulcer by the end of one year. For patients whose $H$ pylori infection is eradicated, the risk of ulcer recurrence is less than $10 \%$.

Interestingly, if $\mathrm{H}$ pylori infection is cleared in patients with duodenal ulcers, smoking does not appear to pose a risk for ulcer recurrence (51). Unfortunately, compliance with the available complicated three- or four-agent treatment therapies remains a problem (52). Also, the long term safety of bismuth needs to be clarified; bismuth levels in urine remain elevated for weeks after therapy with bismuth-containing compounds (53). Unfortunately, in vitro sensitivity of $\mathrm{H}$ pylori to antibiotics does not predict drug efficacy in vivo $(54,44)$. Recurrent $H$ pylori infection may occur rapidly after initial clearance (44), and the strain that emerges is usually identical to the original infecting strain (56). If H pylori is absent six weeks after completion of therapy (eradication), cultures will usually remain negative after one year (49). Thus, it is pos- sible that ulcer disease - and not just ulcers - may be cured by treating the $H$ pylori infection effectively. If this hypothesis is confirmed in future studies, then medical or surgical maintenance therapy may become a thing of the past. And the need to consider today's tomorrow - minimal access surgery - for surgical maintenance therapy may also become a thing of the past.

\section{COMPLICATIONS}

There is a small potential for complications arising from continuous use of $\mathrm{H}_{2}$-receptor antagonists or proton pump inhibitors. For example, there may be interference with the metabolism of some medications, and there often is mild hypergastrinemia (the biological significance of which is unknown). Intergastric acidity is decreased more by omeprazole $(-94 \%)$ than after proximal gastric vagotomy $(-78 \%)$, but plasma gastrin concentrations are increased more after proximal gastric vagotomy $(+284 \%)$ than during treatment with omeprazole $(+186 \%)$ (57). There is no evidence that $\mathrm{H}_{2}$ receptor antagonists or proton pump inhibitors cause gastric cancer; postcimetidine surveillance for up to 10 years does not indicate an increased incidence of carcinoma of the stomach 
or esophagus (58). Case-control studies have also suggested that long term use of $\mathrm{H}_{2}$-receptor antagonists does not predispose to gastric cancer (59). Gastric surgery may be associated with the later development of stump cancer, but the relative risk of postgastric surgery carcinoma is highly disputed.

Cimetidine may reduce serum cortisol concentrations (which may be reversed by taking ascorbic acid [60]), an effect not seen with ranitidine. Cimetidine inhibits the plasma aldosterone response to angiotensin II, whereas this does not occur with ranitidine (61). H2-receptor antagonists may rarely cause a disturbance of cardiac rate and rhythm (62). Famotidine, but not cimetidine or ranitidine, may have a small negative inotropic influence on cardiac performance (63). The hepatic cytochrome P450 enzyme systems are inhibited in varying degrees by the different $\mathrm{H}_{2}$-receptor antagonists and by omeprazole $(64,65)$, but the clinical importance of this interaction, while noteworthy, may be small.

While initial reports suggested that genotoxicity might be associated with the use of omeprazole $(66,67)$, methodological considerations have been raised and differences between studies may be based, in part, on the species of rat used (68-72). A technique using hydroxyurea has suggested a weak positive genotoxicity effect of omeprazole at a dose of $100 \mathrm{mg} / \mathrm{kg}$ (73), but omeprazole did not affect ${ }^{3} \mathrm{H}$-thymidine uptake in purified parietal cells (74). It is unlikely that omeprazole has a significant genotoxicity effect.

Cimetidine and ranitidine, but not famotidine, may inhibit gastric alcohol dehydrogenase slightly (75-77), but the differences are small and the clinical significance is unlikely to be important (78). If $\mathrm{H}_{2}$-receptor antagonists are

\section{REFERENCES}

1. Gustavsson S, Nyren O. Time trends in peptic ulcer surgery, 1956 to 1986. Ann Surg 1989;210:704-9.

2. Taylor TV. Current indications for elective peptic ulcer surgery. $\mathrm{Br} \mathrm{J}$ Surg 1989;76:427-8.

3. Lauritsen K, Rutgersson K, Bolling E, et al. Omeprazole 20 or $40 \mathrm{mg}$ daily for abruptly stopped there may be a brief period of rebound of gastric acid hyperacidity, particularly at night-time (79); this lasts for less than one week and may not be clinically important.

\section{SURGERY: RECURRENCE, REOPERATION AND DEATHS}

Proximal gastric vagotomy is widely practised to treat peptic ulcer disease except in cases of prepyloric ulcers, pyloric obstruction, and combined duodenal and gastric ulcers $(80)$. The 10 - to 20-year postoperative recurrence rate varies widely and has been reported to be $15 \%$, with $80 \%$ of the recurrences occurring within five years and no recurrences after 13 years (81). Others have noted a $12 \%$ recurrence rate after 10 years (82). A five- to 15 -year followup after proximal gastric vagotomy demonstrated a recurrence rate of $11 \%$ (83); $71 \%$ of these recurrences occurred in the first five years, with only one recurrence in 200 patients occurring later than 10 years after surgery. However, late recurrences do sometimes occur (84). Kaplan-Meier estimates of the probabilities of recurrence at five and 10 years after proximal gastric vagotomy performed at the Mayo Clinic were 6 and $12 \%$ for duodenal ulcers, $16 \%$ for gastric ulcers, and 12 and $39 \%$ for pyloric and prepyloric ulcers. The endoscopic recurrence rate after proximal gastric vagotomy when patients were followed five to 10 years gave a total recurrence rate of $13.9 \%$, with $24.3 \%$ recurrence rate for pyloric ulcers and $28.8 \%$ for prepyloric ulcers (85). However, the reoperation rate was low, only $2.9 \%$, because most of the ulcer recurrences were treated satisfactorily with cimetidine. Thus, patients with postoperative recurrence of duodenal or gastric ulcers will be candidates for $\mathrm{H}_{2}$-receptor antagonists or

healing of duodenal ulcer? A doubleblind comparative study. Eur J

Gastroenterol Hepatol

1992;4:995-1000.

4. Pounder RE. Silent peptic ulceration: Deadly silence or golden silence?

Gastroenterology

1989;96(Suppl):626-31.

5. Armstrong CP, Blower AL.

Non-steroidal anti-inflammatory drugs proton pump inhibitor therapy, and some persons may need low dose maintenance therapy for five to 10 years.

Selective vagotomy and pyloroplasty, proximal gastric vagotomy alone and proximal gastric vagotomy plus pyloroplasty give similar outcome results (86), with an overall death rate less than $1 \%$, a three-year ulcer recurrence rate of $8.3 \%$ and a reoperation rate of $7.5 \%$. Recurrences may be eight times more frequent after proximal gastric vagotomy than after Billroth I resection (87).

The mortality rates associated with elective or urgent surgery are higher in older than in younger persons (88). For this reason, the decision to use medical therapy or to avoid surgical therapy must be influenced by the patient's age.

\section{COST-EFFECTIVENESS}

The three important criteria for comparing different types of treatment of the same disease are mortality, morbidity and cost (89). While maintenance therapy is effective for most individuals, the therapy is expensive (approximately \$500/year in Canada). In the United States, proximal gastric vagotomy is more expensive than medical therapy, but is the least expensive therapeutic option in Germany (90). Canadian figures are not available. Laparoscopic selective vagotomies have been performed $(91,92)$. With the prospect of markedly reducing the duration of hospital stays via minimal access surgery, the cost factor of surgery may become even less, and the surgical option for the long term suppression of acid secretion to maintain healing of duodenal and gastric ulcers may become even more desirable in the future. This is, of course, unless peptic ulcer disease can be cured by effectively eradicating $H$ pylori!

and life threatening complications of peptic ulceration. Gut 1987;28:527-32.

6. Soll AH. Duodenal ulcer and drug therapy. In: Sleisinger MH, Fordtran JS, eds. Gastrointestinal Disease: Pathophysiology, Diagnosis, Management, 4th edn. Philadelphia: WB Saunders, 1989:814-79.

7. Boyd EJ, Wilson JA, Wormsley KG. Safety of ranitidine maintenance 
treatment of duodenal ulcer. Scand J Gastroenterol 1984;19:394-400.

8. Boyd EJS, Penston JG, Johnston DA, Wormsley KG. Does maintenance therapy keep duodenal ulcers healed? Lancet 1988;i:1324-7.

9. Bianchi Porro G, Parente F. Duodenal ulcers resistant to $\mathrm{H}_{2}$ blockers: $\mathrm{An}$ emerging therapeutic problem. Scand ] Gastroenterol 1988;23(Suppl 153):81-8.

10. Domschke W, Lam SK, Pounder RE, Andersen D. $\mathrm{H}_{2}$-blocker-resistant duodenal ulceration. Gastroenterol Intl 1989;2:85-91.

11. Pounder RE. Duodenal ulcers that are difficult to heal. Br Med J 1988;297:1560-1.

12. Pounder RE. What is an intractable duodenal ulcer and how should it be managed? Aliment Pharmacol Ther 1987;1(Suppl 1):439S-46S.

13. Reynolds JC. Famotidine therapy for active duodenal ulcers: A multivariate analysis of factors affecting early healing. Ann Intern Med 1989;111:7-14.

14. Walan A, Bader J-P, Classen M, et al. Effect of omeprazole and ranitidine on ulcer healing and relapse rates in patients with benign gastric ulcer. N Engl J Med 1989;320:69-75.

15. Collen MJ, Stanczak VJ, Ciarleglio CA. Refractory duodenal ulcers (non-healing duodenal ulcers with standard doses of antisecretory medication). Dig Dis Sci 1989;34:233-7.

16. Savarino V, Mela GS, Scalabrini P, Celle $\mathrm{G} . \mathrm{H}_{2}$-receptor antagonist non-responders. Lancet 1987;ii:1281.

17. Deakin M, Williams JG. $\mathrm{H}_{2}$-receptor antagonist non-responders. Lancet $1988 ; \mathrm{i}: 127-8$.

18. Johnston D, Wormsley KG. $\mathrm{H}_{2}$-receptor antagonist non-responders. Lancet 1988;i:129.

19. Tytgat GNJ, Lamers CBHW, Hameeteman W, Jansen JMBJ, Wilson JA. Omeprazole in peptic ulcers resistant to histamine $\mathrm{H}_{2}$-receptor antagonists. Aliment Pharmacol Ther 1987;1:31-8.

20. Delle Fave G, Annibale B, Puoti M, Corleto V, Pasquali A, D'Ambra G. The refractoriness to $\mathrm{H}_{2}$-antagonists in healing duodenal ulcer is due to the loss of their antisecretory efficacy. Gastroenterology 1988;94:A94.

21. Brunner G, Creuzfeldt W, Harke U, Lamberts R. Therapy with omeprazole in patients with peptic ulcerations resistant to extended high-dose ranitidine treatment. Digestion 1988;39:80-90.

22. Bianchi Porro G, Parente F, Lazzaroni M. Tripotassium dicitrato bismuthate (TDB) versus two different dosages of cimetidine in the treatment of resistant duodenal ulcers. Gut 1987;28:907-11.

23. Wagmer S, Freose J, Bar W, Schulz M, Schmidt FW. Bismuth subsalicylate in the treatment of refractory peptic ulcers in patients with Campylobacter pylori infection. Gastroenterology 1989;96:A532.

24. Primrose JN, Axon ATR, Johnston D. Highly selective vagotomy and duodenal ulcers that fail to respond to $\mathrm{H}_{2}$-receptor antagonists. $\mathrm{Br} \mathrm{Med} \mathrm{J}$ 1988;296:1031-5.

25. Lane MR, Lee SP. Recurrence of duodenal ulcer after medical treatment. Lancet 1988;i:1147-9.

26. Wormsley KG. Ulcer disease: Medical treatment. Curr Opin Gastroenterol 1988;4:968-80.

27. Barberani F, Della Spoletina A, Fatale GP. Long-term treatment of the duodenal and gastric ulcer using ranitidine: Preliminary results of an open and controlled study with a new therapeutic regime. Ital J Gastroenterol 1988;18:57.

28. Blasi A, Mangiameli A, Castelli G, et al. Long-term (24 month) ranitidine in prevention of duodenal ulcer relapses: Comparison of continuous and seasonal treatment. Ital J Gastroenterol 1987;19:141-4.

29. Bardhan KD. Intermittent treatment of duodenal ulcer for long-term medical management. Postgrad Med ] 1988;64(Suppl 1):40-6.

30. Bolin TD, Davis AE, Duncombe VM, Billington $\mathrm{B}$. Role of maintenance sucralfate in prevention of duodenal ulcer recurrence. Am J Med 1987;83:91-4.

31. Behar J, Roufail W, Thomas E, Keller F, Dernbach W, Tesler MA. Efficacy of sucralfate in the prevention of recurrence of duodenal ulcers. J Clin Gastroenterol 1987;9(Suppl 1):23-30.

32. Blum AL, Bethge $H$. Sucralfate in the treatment and prevention of gastric ulcer. Gastroenterology 1988;94:A39.

33. Rutgeerts $P$, Vantrappen $G$, Brassine A, et al. Prevention of duodenal ulcer recurrence by pirenzepine $50 \mathrm{mg}$ twice daily. J Clin Gastroenterol 1987;9(Suppl 3):314-6.

34. The ACG Committee on FDA-Related Matters Under The Primary Authorship of SJ Sontag. Current status of maintenance therapy in peptic ulcer disease. Am J Gastroenterol 1988;83:607-17.

35. Wormsley KG. Long-term treatment of duodenal ulcer. Postgrad Med J 1988;64(Suppl 1):47-53.

36. Freston JW. $\mathrm{H}_{2}$-receptor antagonists and duodenal ulcer recurrence: Analysis of efficacy and commentary on safety, costs and patient selection. Am J Gastroenterol 1987;82:1242-9.
37. Walan A, Bianchi Porro G, Hentschel E, Bardhan KD, Delattre M. Maintenance treatment with cimetidine in peptic ulcer disease for up to 4 years. Scand J Gastroenterol 1987;22:397-405.

38. Bardhan KD for Anglo-Irish Cimetidine Long-Term Study Group. Six years of continuous cimetidine treatment in peptic ulcer disease: Efficacy and safety. Aliment Pharmacol Ther 1988;2:395-406.

39. Penston JG, Wormsley KG. Long-term treatment of duodenal ulcers. Gastroenterology 1988;94:A349.

40. Sonnenberg A. Comparison of different strategies for treatment of duodenal ulcer. Br Med J 1985;290:1185-7.

41. Megraud F, Lamouliatte $H$. Helicobacter pylori and duodenal ulcer. Dig Dis Sci 1992;37:769-72.

42. Marshall BJ, McGechie DB, Rogers PA, Glancy RJ. Pyloric Campylobacter infection and gastroduodenal disease. Med J Aust 1985;142:439-44.

43. Coghlan JG, Gilligan D, Humphries $\mathrm{H}$, et al. Campylobacter pylori and recurrence of duodenal ulcers - a 12-month follow-up study. Lancet 1987;ii:1109-11.

44. Rauws EAJ, Langenberg W, Houthoff $\mathrm{HJ}$, Zanen HC, Tytgat GNJ. Campylobacter pyloridis-associated chronic active antral gastritis: A prospective study of its prevalence and the effects of antibacterial and antiulcer treatment. Gastroenterology 1988;94:33-40.

45. Goodwin CS, Marshall BJ, Blincow ED, Wilson DJ, Blackbourn S, Phillips M. Prevention of nitroimidazole resistance in Campylobacter pylori by co-administration of colloidal bismuth subcitrate: Clinical and in vitro studies. J Clin Pathol 1988;41:207-10.

46. Lamouliatte H, Megraud F, DeMascarel A, Roux D, Quinton A. Campylobacter pyloridis and epigastric pain: Endoscopic, histological and bacteriological correlations. Gastroenterol Clin Biol 1987;11:212-6.

47. Borody T], Cole P, Noonan S, et al. Long-term Campylobacter pylori recurrence post eradication. Gastroenterology 1988;94:43.

48. Lambert JR, Borromeo M, Korman MG, Hansky J, Eaves ER. Effect of colloidal bismuth (De-Nol) on healing and relapse of duodenal ulcers - role of Campylobacter pyloridis.

Gastroenterology 1987;92:1489.

49. Marshall BJ, Goodwin CS, Warren JR, et al. Prospective double-blind trial of duodenal ulcer relapse after eradication of Campylobacter pylori. Lancet $1988 ; \mathrm{ii}: 1437-42$.

50. Rauws EAJ, Tytgat G. Cure of 
duodenal ulcer associated with eradication of Helicobacter pylori. Lancet 1990;i:1233-5.

51. George LL, Borody TJ, Andrews P, et al. Cure of duodenal ulcer after eradication of Helicobacter pylori. Med ] Aust 1990;153:145-9.

52. Graham DY, Lew GM, Malaty HM, et al. Factors influencing the eradication of Helicobacter pylori with triple therapy. Gastroenterology 1992;102:493-6.

53. Hamilton I, Worsley BW, O'Connor HJ, Axon AT. Effects of tripotassium dicitrato bismuthate (TDB) tablets or cimetidine in the treatment of duodenal ulcer. Gut 1983;24:1148-51.

54. Graham DY, Klein PD, Opekun AR, et al. In vivo susceptibility of Campylobacter pylori. Am J Gastroenterol 1989;84:233-8.

55. McNulty CAM, Gearty JC, Crump B, et al. Campylobacter pyloridis and associated gastritis: Investigator blind, placebo controlled trial of bismuth salicylate and erythromycin ethylsuccinate. Br Med J 1986;293:645-9.

56. Langenberg W, Rauws EA, Widjojokusumo A, Tytgat GN, Zanen HC. Identification of Campylobacter pyloridis isolates by restriction endonuclease DNA analysis. J Clin Microbiol 1986;24:414-7.

57. Lind T, Cederberg C, Olausson $\mathrm{O}$, Olbe L. 24-hour intragastric acidity and plasma gastrin concentration after omeprazole treatment and after proximal gastric vagotomy in duodenal ulcer patients. Gastroenterology 1990;99:1593-8.

58. Colin-Jones DG, Langman MIS, Lawson DH, Logan RFA, Paterson KR, Vessey MP. Post-cimetidine surveillance for up to ten years: Incidence of carcinoma of the stomach and oesophagus. Q J Med 1991;78:13-9.

59. LaVecchia C, Negri E, D'Avanzo B, Franceschi S. Histamine-2-receptor antagonists and gastric cancer risk. Lancet 1990;336:355-7.

60. Boidin MP, Stuurman A, Erdmann W. Inhibition of steroidogenesis by cimetidine in man. A double-blind, prospective study. Scand J Gastroenterol 1988;23(Suppl 154):41-5.

61. Fujimura A, Ohashi K, Sudo T, Sakamoto K, Oka T, Ebihara A. Effects of $\mathrm{H}_{2}$-receptor antagonists on plasma aldosterone response to angiotensin II in healthy subjects: Comparison of cimetidine and ranitidine. J Clin Pharmacol 1989;29:230-3.

62. Tanner LA, Arrowsmith JB. Bradycardia and $\mathrm{H}_{2}$ antagonists. Ann Intern Med 1988;109:434-5. (Lett)
63. Kirch W, Halabi A, Linde M, Santos SR, Ohnhaus EE. Negative effects of famotidine on cardiac performance assessed by noninvasive hemodynamic measurements. Gastroenterology 1989;96:1388-92.

64. Leiber BL, Antell LA. Cimetidine and the cytochrome $\mathrm{P}=450$ system. Am J Gastroenterol 1988;83:1006.

65. Chenery RJ, Ayrton A, Oldham HG, Norman SJ, Standring P. The interaction of omeprazole with rat liver cytochrome P450 mediated monooxygenase reactions in vivo and in vitro. Biochem Pharmacol 1988;37:1407-14.

66. Burlinson B, Morriss SH, Gatehouse DG, Tweats DJ. Genotoxicity studies of gastric acid inhibiting drugs. Lancet 1990;335:419-20.

67. Burlinson B, Morris S, Gatehouse DG, Tweats DJ, Jackson MR. Uptake of tritiated thymidine by cells of the rat gastric mucosa after exposure to loxtidine or omeprazole. Mutagenesis 1991;6:11-8.

68. Wright NA. DNA synthesis and genotoxicity. Digestion 1990;47(Suppl 1):24-30.

69. Larsson H, Fryklund J, Helander HF, Wallmark B. Partial pronase digestion of rat gastric mucosa isolates cells undergoing replicative DNA synthesis. Mutagenesis 1991;6:3-9.

70. Holt S. Antisecretory therapy and genotoxicity. Dig Dis Sci 1991;36:545-7.

71. Scott D, Reuben MA, Zampighi G, Sachs G. Cell isolation and genotoxicity assessment in gastric mucosa. Dig Dis Sci 1990;35:1217-25.

72. Fraser AG, Debnam ES, Dhillon AP, Pounder RE. The effect of variation in strain of rat on gastric mucosal proliferation after treatment with antisecretory drugs. Gastroenterology 1991;100:A66.

73. Furihata C, Hirose K, Matsushima T. Genotoxicity and cell proliferative activity of omeprazole in rat stomach mucosa. Mutat Res 1991;262:73-6.

74. Fryklund J, Falknas A-K, Helander HF, Wallmark B. Omeprazole does not affect insensitive ${ }^{3} \mathrm{H}$-thymidine uptake in purified parietal cells. Gastroenterology 1991;100:A67.

75. Caballeria J, Baraona E, Rodamilans M, Lieber CS. Effects of cimetidine on gastric alcohol dehydrogenase activity and blood ethanol levels. Gastroenterology 1989;96:388-92.

76. Roine R, DiPadora C, Pozzato G, Terpin M, Baraona E, Lieber CS. Effects of omeprazole, cimetidine and ranitidine on blood ethanol concentrations. Gastroenterology 1990;98:A114.

77. Caballeria J, Baraona E, Lieber CS.
The ccontribution of the stomach to ethanol oxidation in the rat. Life Sci 1987;41:1021-7.

78. Fraser AG, Prewett EJ, Hudson M, Sawyer AM, Rosalki SB, Pounder RE. The effect of ranitidine, cimetidine or famotidine on low-dose post-prandial alcohol absorption. Aliment Pharmacol Ther 1991;6:263-72.

79. Fullarton GM, McDonald AMI, McColl KEL. Rebound hypersecretion after $\mathrm{H}_{2}$-antagonist withdrawal: A comparative study with nizatidine, ranitidine and famotidine. Aliment Pharmacol Ther 1991;4:391-8.

80. Jordan PH. Surgery for peptic ulcer disease. Curr Probl Surg 1991;28:265-330.

81. Johnston GW, Spencer EF, Wilkinson AJ, Kennedy TL. Proximal gastric vagotomy: Follow-up at 10-20 years. Br J Surg 1991;78:20-3.

82. Kelly KA. Operations for peptic ulcer. Surgery 1991;109:802-3. (Edit)

83. Schache DJ, Masters A, Tovey FI, Heald RJ, Rees M. Long term recurrence patterns following proximal gastric vagotomy. Aust NZ J Surg 1989;59:387-90.

84. Soper NJ, Kelly KA, van Heerden JA, Ilstrup DM. Long-term clinical results after proximal gastric vagotomy. Surg Gynecol Obstet 1989;169:488-94.

85. Muller C, Martineli S, eds. Die Proximal-Selektive Vagotomie in der Behandlung der Gastroduodenalen Ulcuskrankheit. Berlin: Springer-Verlag, 1985.

86. Emås S, Fernström M. Prospective, randomized trial of selective vagotomy with pyloroplasty and selective proximal vagotomy with and without pyloroplasty in the treatment of duodenal, pyloric and prepyloric ulcers. Am J Surg 1985;149:236-43.

87. Jordan PH Jr. Duodenal ulcers and their surgical treatment: Where did they come from? Am J Surg 1985;149:2-14.

88. Langman MJS. Peptic ulcer treatment now and tomorrow. J Clin Gastroenterol 1987;9(Suppl 2):2-6.

89. Wormsley KG. Medical treatment of ulcer disease. Curr Opin Gastroenterol 1989;5:824-35.

90. Sonnenberg A. Costs of medical and surgical treatment of duodenal ulcer. Gastroenterology 1989;96:1445-52.

91. Katkhouda N, Mouiel J. A new technique of surgical treatment of chronic duodenal ulcer without laparotomy by videocoelioscopy. Am J Surg 1991;161:361-9.

92. Bailey RW, Flowers JL, Graham SM, Zucker KA. Combined laparoscopic cholecystectomy and selective vagotomy. Surg Laparosc Endosc 1991;1:45-9. 


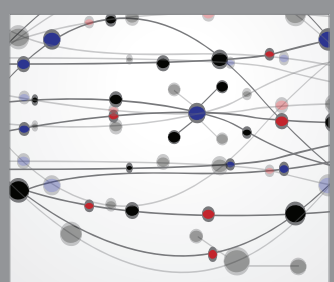

The Scientific World Journal
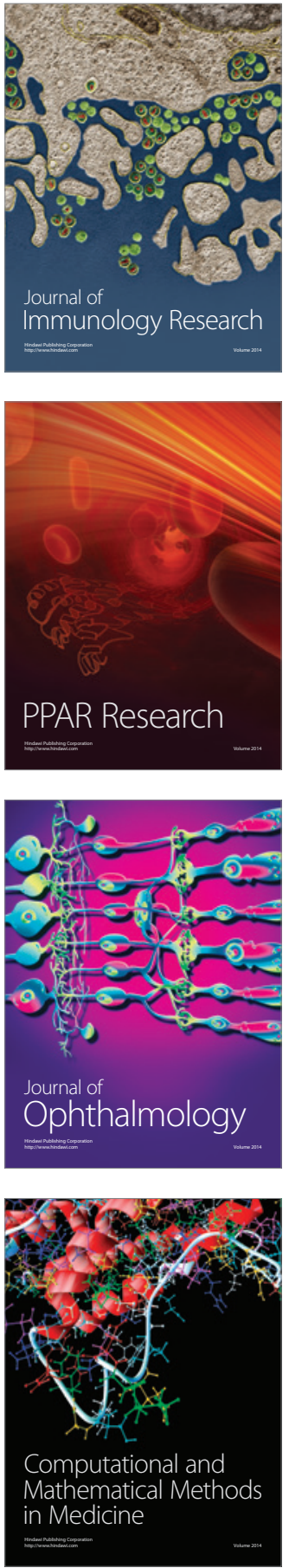

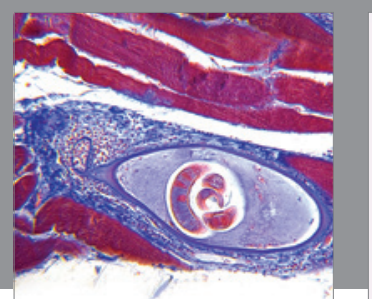

Gastroenterology Research and Practice

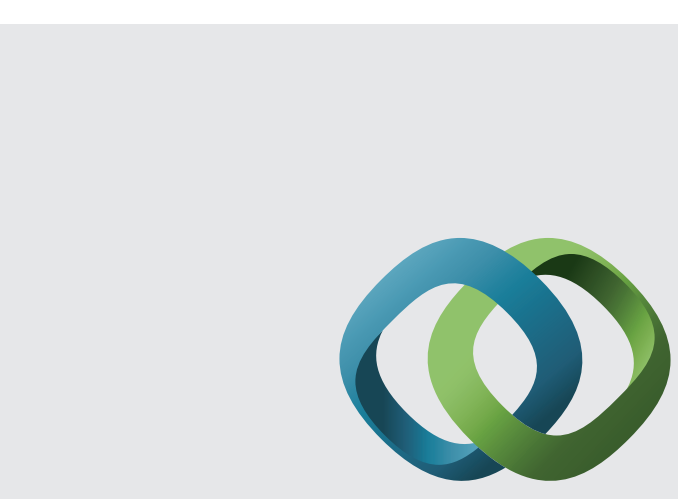

\section{Hindawi}

Submit your manuscripts at

http://www.hindawi.com
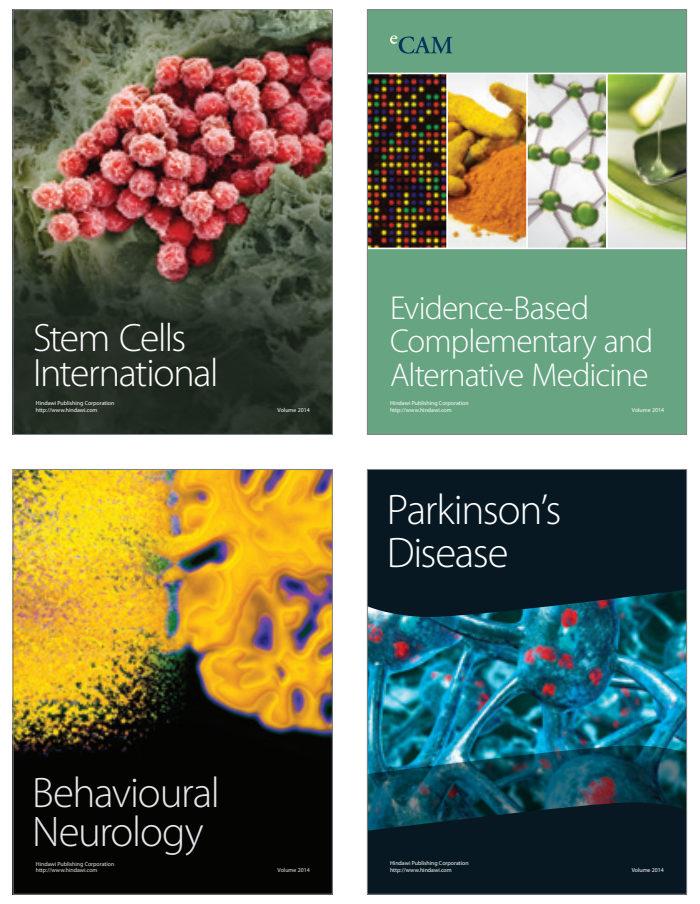
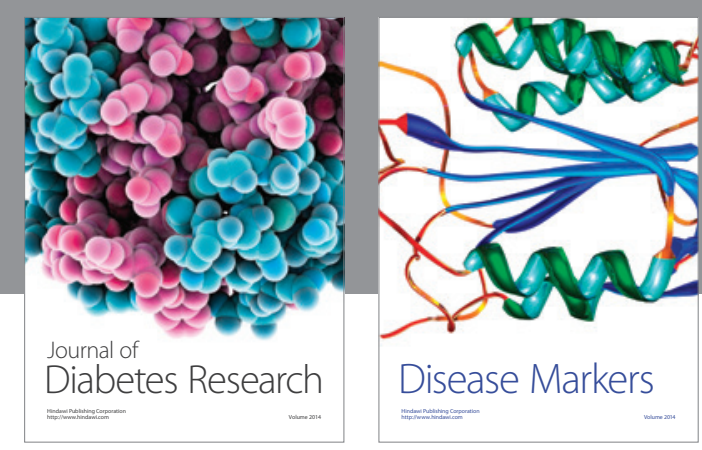

Disease Markers
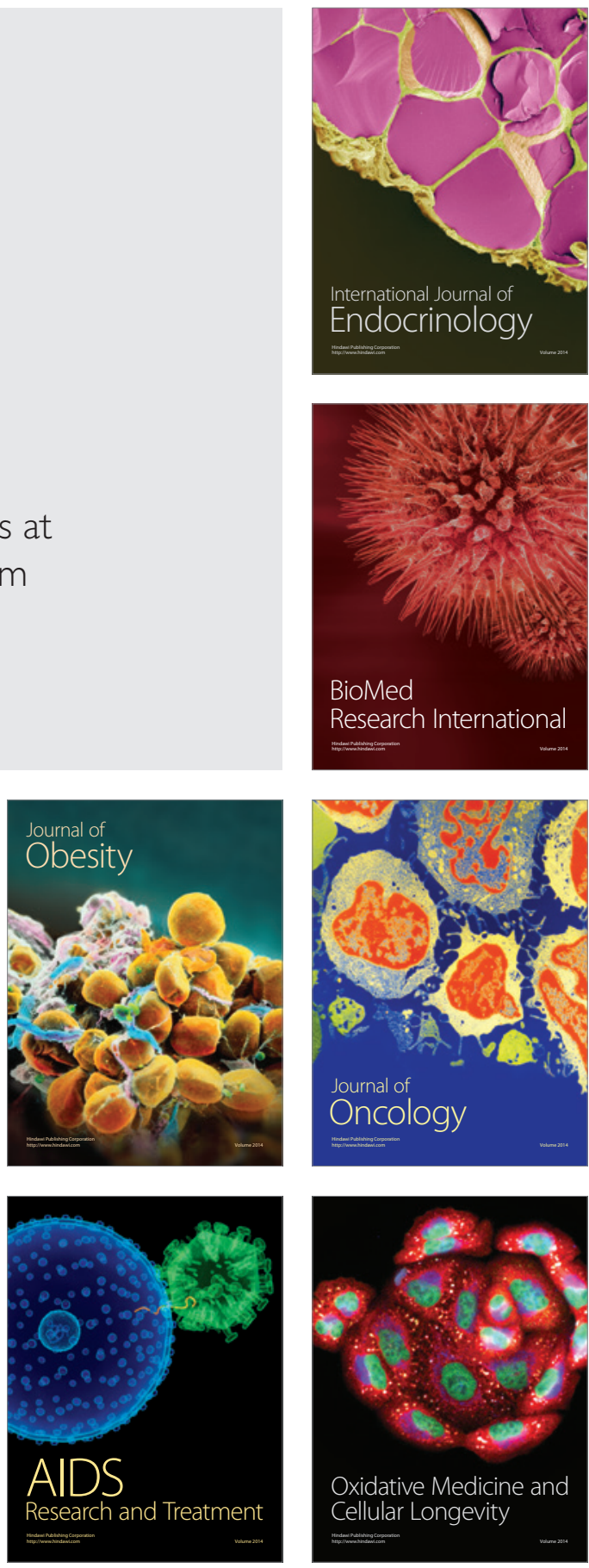